\title{
Improved Regeneration of Shoots from Garlic Callus
}

\author{
M. Koch ${ }^{1}$ Z. Tanami ${ }^{1}$, and R. Salomon ${ }^{2}$ \\ Agricultural Research Organization, P.O. Box 6, Bet Dagan, 50250 Israel
}

Additional index words. Allium sativum, in vitro

Plantlet regeneration from garlic (Allium sativum L.) callus has been suggested as a source of somaclonal variants (Nagasawa and Finer, 1988; Novak et al., 1986), a means of freeing plants from endemic viruses (Abo ElNil, 1977; Koch and Salomon, 1994), and a target for transformation (Myers and Simon, 1993). However, slow callus growth and poor regeneration limits the use of these techniques.

Several medium additives, including plant growth regulators and $\mathrm{N}$, affect regeneration from callus in other Allium species (Dunstan and Short, 1977). Our study tested the effect of several medium additives on the rate of garlic callus growth and shoot regeneration.

One hundred cloves from 10 randomly chosen 'Frankon' garlic bulbs of a uniform lot were peeled, soaked for $1 \mathrm{~h}$ in $3 \% \mathrm{NaOCl}$, and then rinsed $45 \mathrm{~min}$ in three changes of sterile water. The shoot basal plate from a clove plus 1 to $2 \mathrm{~mm}$ of the leaf bases (scales) were excised, cut into two to three explants, and placed (one clove per dish) in plastic petri dishes $(50 \mathrm{~mm}$ in diameter) with $10 \mathrm{ml}$ of callus induction medium. This medium was BDS-based (Dunstan and Short, 1977) with 3 $\mu_{\mathrm{M}}$ 2,4-diclorophenoxyacetic acid (2,4-D), 3 $\mu \mathrm{M} 1 H$-indole- 3 -acetic acid (IAA), $3 \%$ sucrose, and $0.3 \%$ Phytagel (Sigma Chemical Co., St. Louis), adjusted to pH 5.7 before being autoclaved for $20 \mathrm{~min}$ at $121 \mathrm{C}$. Cultures were incubated at $25 \mathrm{C}$ in darkness for 6 weeks, after which the callus was transferred to fresh callus induction medium for another 6 weeks before being used to compare nine additive combinations.

Received for publication 27 June 1994. Accepted for publication 6 Nov. 1994. Contribution from the Agricultural Research Organization, Volcani Center, Bet Dagan, Israel, no. 1399-E, 1994 series. Research supported by the Ministry of Science, Grant 3426 for new immigrant scientists. The cost of publishing this paper was defrayed in part by the payment of page charges. Under postal regulations, this paper therefore must be hereby marked advertisement solely to indicate this fact.

${ }^{1}$ Dept. of Vegetable Crops.

${ }^{2}$ Dept. of Virology. 16-h photoperiod.
These additive combinations included the callus induction medium previously described; five variations of this medium by adding $9 \mu \mathrm{M}$ of the cytokinins 6-benzyladenine (BA) or $\Delta^{2}$ iso-pentenyladenine (2iP), inorganic $\mathrm{N}(2.53$ g additional $\mathrm{KNO}_{3} /$ liter), organic $\mathrm{N}(900 \mathrm{mg}$ casein hydrolysate/liter), or $60 \mathrm{~g}$ additional sucrose/liter and three variations containing alternative combinations of auxin and cytokinins: 5 or $10 \mu \mathrm{M} \mathrm{BA}, 10$ or $20 \mu \mathrm{M} \mathrm{IAA,} \mathrm{and/or}$ $3 \mu \mathrm{M} 4-$ amino-3,5,6-trichloropicolinic acid (picloram). The BDS medium was prepared as previously described; IAA and 2iP were added after autoclaving.

Callus was divided into portions of $270 \pm$ $10 \mathrm{mg}$ fresh weight and placed one portion per plastic petri dish (50 $\mathrm{mm}$ in diameter) containing $10 \mathrm{ml}$ medium. Fifteen cultures were established for each medium. Cultures were incubated at 25C in darkness for 6 weeks. Callus of each culture then was weighed, transferred to plastic petri dishes $(90 \mathrm{~mm}$ in diameter) with $40 \mathrm{ml}$ fresh medium, and incubated as previously described. Final fresh weight of callus was assessed 12 weeks after establishment. Calluses from each medium then were transferred to twenty $100-\mathrm{ml}$ glass jars with plastic lids filled with $30 \mathrm{ml}$ BDS-based regeneration medium $(25 \mu \mathrm{m}$ kinetin and $10 \mu \mathrm{M}$ IAA) and incubated at $25 \mathrm{C}$ with a 16 -h photo- period. The number of regenerated shoots was counted 8 weeks later. Effects of medium supplements on callus weight and number of shoots were compared by analysis of variance; treatments were compared by Duncan's multiple range test.

Callus growth on the standard medium was equal to that in all other media, with the exception of the medium with extra $\mathrm{KNO}_{3}$ (Table 1). Callus grew $\approx 33 \%$ faster on this medium and was friable; callus grown with organic $\mathrm{N}$ did not show improved growth.

Shoot regeneration was best from compact callus grown on the medium with 2,4-D, IAA, and $2 \mathrm{iP}$ (Table 1 ). This additive combination gave a $42.5 \%$ increase in shoot regeneration over calluses grown on similar medium but without $2 \mathrm{iP}$ or with $\mathrm{BA}$ instead of $2 \mathrm{iP}$. The rapidly growing calluses from medium with additional $\mathrm{KNO}_{3}$ had a low regeneration rate.

This improvement in regeneration rate will help develop systems to increase variation in this sterile species.

\section{Literature Cited}

Abo El-Nil, M. 1977. Organogenesis and embryogenesis in callus cultivars of garlic (Allium sativum L.). Plant Sci. Lett. 9:259-264.

Dunstan, D.I. and K.C. Short. 1977. Improved growth of tissue cultures of onion, Allium cepa. Physiol. Plant. 41:70-72.

Koch, M. and R. Salomon. 1994. Serological detection of onion yellow dwarf virus in garlic. Plant Dis. 78:785-788.

Myers, M. and P. Simon. 1993. Callus induction in garlic and its implications for transformation. HortScience 28:498.

Nagasawa, A. and J. Finer. 1988. Induction of morphogenic callus cultures from leaf tissue of garlic. HortScience 23:1068-1070.

Novak, F., L. Havel, and J. Dolezel. 1986. Allium, p. 419-456. In: D.A. Evans, W. Sharp, and R. Ammirato (eds.). Handbook of plant cell culture. vol. 4. MacMillan, New York

Table 1. Garlic callus weight after 6 and 12 weeks of culture (25C, in darkness) on nine BDS-based callus growth media (Duncan and Short, 1977) and the number of shoots regenerated from cultures following transfer to BDS-based regeneration medium ( $25 \mu \mathrm{M}$ kinetin, $10 \mu \mathrm{M}$ IAA) and incubation at $25 \mathrm{C}$ with a

\begin{tabular}{|c|c|c|c|c|}
\hline \multirow{3}{*}{$\begin{array}{l}\text { Medium } \\
\text { additives }\end{array}$} & \multicolumn{3}{|c|}{ Mean fresh wt $(\mathrm{g})$} & \multirow{3}{*}{$\begin{array}{c}\text { Mean no. } \\
\text { shoots/g } \\
\text { callus }\end{array}$} \\
\hline & \multicolumn{3}{|c|}{ Culture (wks) } & \\
\hline & 0 & 6 & 12 & \\
\hline $3 \mu \mathrm{M} 2,4-\mathrm{D}, 3 \mu \mathrm{M}$ IAA & 0.27 & $2.65 \mathrm{~b}^{\mathrm{z}}$ & $7.59 \mathrm{~b}$ & $0.41 \mathrm{~b}$ \\
\hline $3 \mu_{\mathrm{M}} 2,4-\mathrm{D}, 3 \mu_{\mathrm{M}} \mathrm{IAA}, 9 \mu_{\mathrm{M}}$ BA & 0.26 & $2.47 \mathrm{~b}$ & $7.07 \mathrm{~b}$ & $0.40 \mathrm{~b}$ \\
\hline $3 \mu \mathrm{M} 2,4-\mathrm{D}, 3 \mu_{\mathrm{M}} \mathrm{IAA}, 9 \mu_{\mathrm{M}} 2 \mathrm{iP}$ & 0.27 & $2.26 \mathrm{~b}$ & $7.93 \mathrm{~b}$ & $0.57 \mathrm{a}$ \\
\hline $3 \mu \mathrm{M} 2,4-\mathrm{D}, 3 \mu \mathrm{M}$ IAA, $9 \%$ sucrose & 0.27 & $1.43 \mathrm{c}$ & $3.26 \mathrm{c}$ & $0.40 \mathrm{~b}$ \\
\hline \multicolumn{5}{|l|}{$3 \mu \mathrm{M} 2,4-\mathrm{D}, 3 \mu \mathrm{M}$ IAA, } \\
\hline $900 \mathrm{mg}$ casein hydrolysate/liter & 0.27 & $2.33 \mathrm{~b}$ & $6.64 \mathrm{~b}$ & $0.48 \mathrm{ab}$ \\
\hline \multicolumn{5}{|l|}{$3 \mu \mathrm{M} 2,4-\mathrm{D}, 3 \mu \mathrm{M}$ IAA, } \\
\hline $2.5 \mathrm{~g}$ extra $\mathrm{KNO}_{3} /$ liter & 0.26 & $3.50 \mathrm{a}$ & $12.04 \mathrm{a}$ & $0.13 \mathrm{c}$ \\
\hline $5 \mu \mathrm{M}$ BAP, $3 \mu \mathrm{M}$ picloram & 0.28 & $2.50 \mathrm{~b}$ & $7.23 \mathrm{~b}$ & $0.40 \mathrm{~b}$ \\
\hline $5 \mu \mathrm{M}$ BAP, $10 \mu \mathrm{M}$ IAA & 0.28 & $2.40 \mathrm{~b}$ & $3.54 \mathrm{c}$ & $0.37 \mathrm{~b}$ \\
\hline $10 \mu \mathrm{M}$ BAP, $20 \mu \mathrm{M}$ IAA & 0.27 & $2.18 b$ & $4.84 \mathrm{c}$ & $0.37 \mathrm{~b}$ \\
\hline Mean & 0.27 & 2.41 & 6.68 & 0.39 \\
\hline
\end{tabular}

${ }^{2}$ Mean separation within a column by Duncan's multiple range test at $P \leq 0.05$. 